(c) American Dairy Science Association, 2004.

\title{
Hot Topic: Effects of Frequent Milking in Early Lactation on Milk Yield and Udder Health
}

\author{
G. E. Dahl, ${ }^{1}$ R. L. Wallace, ${ }^{2}$ R. D. Shanks, ${ }^{1}$ and D. Lueking ${ }^{3}$ \\ ${ }^{1}$ Department of Animal Sciences and \\ ${ }^{2}$ College of Veterinary Medicine, \\ University of Illinois, Urbana 61801 \\ ${ }^{3}$ Lueking Dairy Farm, Centralia, IL 62250
}

\begin{abstract}
A field study was conducted to evaluate the influence of milking frequency ( 3 or 6 times/d [3× or $6 \times$, respectively]) during the initial $21 \mathrm{~d}$ of lactation on milk and milk component yield and mammary gland health as indicated by somatic cell count. During 2 seasons, spring and fall, multiparous cows were milked 6 times/ d until d 21 of lactation and then returned to the 3 times/d frequency for the remainder of lactation (6x; $\mathrm{n}=9$ ). Multiparous cows milked 3 times/d from the beginning of lactation served as a control group ( $3 \times ; n=$ 17). With the exception of milking frequency, all other aspects of management, including housing, milk harvesting, and feeding, were identical between the groups and were consistent with industry norms. Retrospective analysis of Dairy Herd Improvement Association records was used to evaluate milk yield, milk component yield, and somatic cell scores. As expected, $6 \times$ cows produced more milk on the first test day than $3 \times$ cows. Compared with $3 \times$ cows, higher milk yields persisted for $6 \times$ cows from test day 2 through 6 , indicating a persistent effect of early lactation milking frequency on milk yield potential for that lactation. Milk component yield followed a similar pattern: $6 \times$ cows produced significantly more protein, fat, and total solids than did control cows throughout the study. With regard to udder health, $6 \times$ cows had lower somatic cell counts at the first test day relative to $3 \times$ cows and had reduced somatic cell scores for the first 3 mo of lactation, which suggests that early lactation milking frequency influences the mammary gland capacity to resist infection in addition to improving milk production efficiency.
\end{abstract}

(Key words: early lactation, frequent milking, somatic cell score)

Abbreviation key: $3 \times=$ milking 3 times $/ \mathrm{d}, \mathbf{6} \times=$ milking 6 times $/$ d, $\mathbf{P R L}=$ prolactin.

Received July 18, 2003.

Accepted December 19, 2003.

Corresponding author: G. Dahl; E-mail: gdahl@uiuc.edu.
Increasing the frequency of milk removal increases milk production in cattle as it does in many species (Stelwagen, 2001). Indeed, this is a common management approach to maximize production per cow and to fully optimize capital investment in machinery and facilities. One obvious drawback is the increase in variable costs, mainly labor, required to reap the higher milk yield. Traditionally, this technique has been employed throughout lactation, but recent evidence suggests that frequent milking, appropriately timed within the lactation cycle, can have persistent effects, eliminating some of the higher costs while maintaining higher yields. Bar-Peled et al. (1995) observed higher production in cows milked 6 times/d $(\mathbf{6} \times)$ relative to 3 times/d (3 $\times)$ during the initial $42 \mathrm{~d}$ of lactation. More importantly, the production response was strikingly persistent following a return to $3 \times$ from $6 \times$ at $\mathrm{d} 42$. That is, cows milked $6 \times$ continued to yield more milk even after milking frequency was reduced to $3 \times$. A preliminary report by Henshaw et al. (2000) confirmed, under field conditions, that milking cows $6 \times$ in early lactation produces persistent improvements in milk yield even after cows returned to $3 \times$. For the first $42 \mathrm{~d}$ of lactation, cows were milked $3 \times$ at 8 -h intervals or $6 \times$ at approximately 4 - to 5 -h intervals. After d 42 , all cows were milked $3 \times$ for the rest of the study, which lasted through 38 wk of lactation. Relative to those milked $3 \times$, multiparous cows milked $6 \times$ produced more milk throughout the study.

Milk yield, however, may not be the only benefit of increased milking frequency in early lactation. Frequent milk removal is associated with reductions in somatic cells (Kelly et al., 1998; Smith et al., 2002), a general indicator of mammary gland health. Yet no previous studies have reported the effect of frequent milking in early lactation on any aspect of udder health. Further, the lower limit of number of days that cows need to be milked at higher frequency to observe a persistency response, particularly under management conditions observed in the field, has not been identified. The objective of the present study was to evaluate the effect of milking $6 \times$ vs. $3 \times$ for the initial $21 \mathrm{~d}$ of lactation on milk yield and udder health as indicated by SCS. 


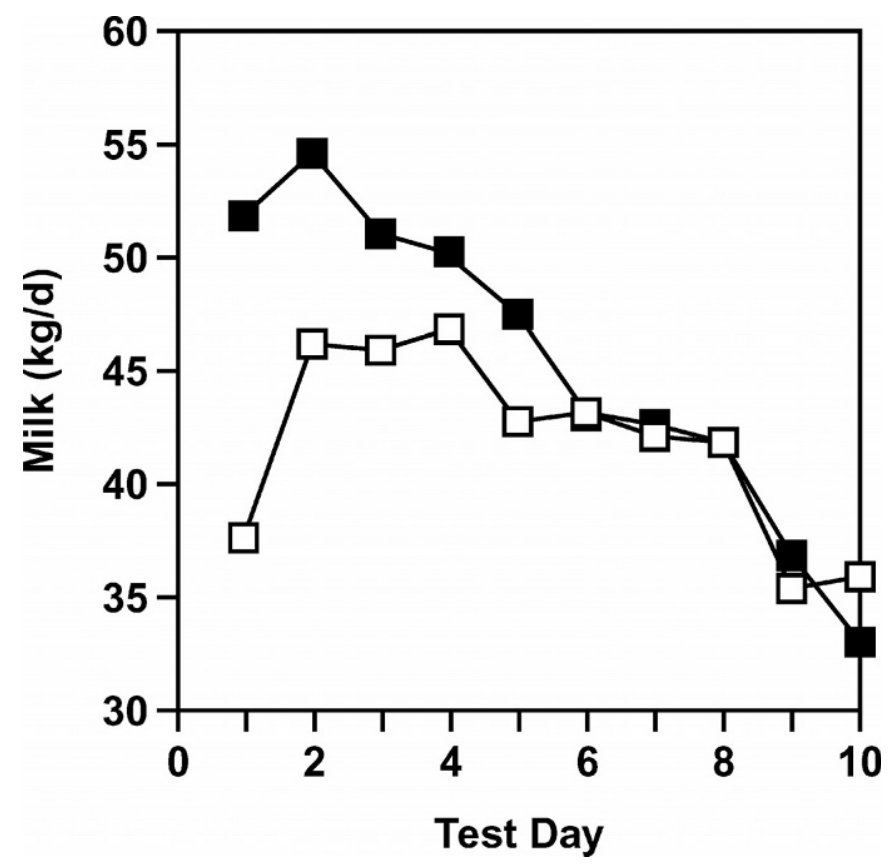

Figure 1. Test day average (least squares mean) milk yield of cows milked 6 times/d $(6 \times ; \mathbf{n} ; \mathrm{n}=9)$ for the initial $21 \mathrm{~d}$ of lactation or milked 3 times/d ( $3 \times ; \square ; n=17)$ for the initial $21 \mathrm{~d}$ of lactation. All cows were milked $3 \times$ for the remainder of lactation. Standard error of the mean ranged from 2.04 to $3.11 \mathrm{~kg} / \mathrm{d}$. Test day average milk yields past test day 5 were not significantly different between $3 \times$ and $6 \times$ treatments.

During Spring and Fall 2001, 9 cows were assigned at calving to $6 \times$ milking for $21 \mathrm{~d}$ after parturition. All remaining multiparous cows in the herd $(n=17)$ that calved within 2 mo of the $6 \times$ cows were used as controls to test for main effects of $6 \times$ milking on milk and milk component yield and udder health. All work was completed at Lueking Dairy, a commercial farm located in Centralia, Illinois. Milking times were 0600, 1400, and $2200 \mathrm{~h}$ for all cows, and $6 \times$ cows were milked an additional 3 times at 0800, 1600, and $2400 \mathrm{~h}$. Cows were housed together and managed according to common commercial techniques, including ad libitum TMR feeding (31.1\% corn silage, $31.1 \%$ ground corn, $16.6 \%$ alfalfa hay, $10.4 \%$ corn gluten, $8.3 \%$ cottonseed, $1.5 \%$ urea, and $1 \%$ vitamin-mineral premix), bST according to label directions, and DHIA testing of fluid milk and component production. Fresh feed was offered 3 times/d after milking.

Data was collected from Dairy Herd Improvement for test day and lactation totals. Lactation totals included DHI variables of summit milk, peak milk, days in milk at peak, 305-d milk yield, mature equivalent $305-\mathrm{d}$ milk yield, actual corrected 305-d milk, and lactation average SCS. Because cows were assigned to treatments in groups based on sequence of freshening, covariates were included in the model for PTA for milk and inbreeding (Young et al., 1969). Therefore, model for lactation totals included main effect of treatment (i.e., $3 \times$ vs. $6 \times$ for $21 \mathrm{~d}$ ) and covariates for PTA milk and inbreeding. Least squares means for $3 \times$ and $6 \times$ milking were adjusted for differences in PTA and inbreeding of the cows in the study. Some caution must be used in interpreting the results of the lactation totals because variables were not independent. Test day data included milk per day and SCS on test day for 10 test d per cow. As a part of a repeated measures analysis, each test day was analyzed separately with a model that included main effect of treatment ( $3 \times$ vs. $6 \times$ for $21 \mathrm{~d}$ ) and covariates for PTA milk and inbreeding. All cows were milked an equal number of times per day during the 2nd through 10th test days. Cows milked $3 \times$ averaged 103 \pm 125 for PTA milk with a range of -811 to 974 . Cows milked $6 \times$ averaged $185 \pm 178$ for PTA milk with a range of -674 to 983 . Inbreeding of cows milked $3 \times$ averaged $4.5 \pm 0.4 \%$ with a range of 2 to $8 \%$, whereas $6 \times$ cows averaged $4.1 \pm 0.6 \%$ with a range of 2 to $9 \%$.

Relative to a $3 \times$ milking frequency, cows milked at $6 \times$ produced more milk from the first DHIA test day, and greater milk yields persisted through the 6th test day (Figure 1). Overall, $6 \times$ cows produced $1,118 \mathrm{~kg}$ more milk over the 305-d lactation than did cows milked $3 \times$

Table 1. Analysis of variance, including mean squares (MS) and mean comparisons of various production traits of cows milked 3 times/d (3x) or 6 times/d $(6 \times)$ for the initial $21 \mathrm{~d}$ of lactation.

\begin{tabular}{lrrrrr}
\hline Trait & \multicolumn{1}{c}{$3 \times$} & \multicolumn{1}{c}{$6 \times$} & Error MS & Treatment MS & $P$ \\
\hline Summit milk, kg & $46.7 \pm 1.9$ & $55.1 \pm 1.8$ & 53 & 362 & 0.017 \\
Peak milk, kg & $51.1 \pm 1.8$ & $57.0 \pm 1.8$ & 45 & 164 & 0.071 \\
DIM at peak & $101.0 \pm 12$ & $56.4 \pm 11$ & 1965 & 12,671 & 0.020 \\
$\begin{array}{l}\text { Actual 305-d milk } \\
\text { production, kg }\end{array}$ & $12,255 \pm 364$ & $13,373 \pm 462$ & $1,541,819$ & $5,300,873$ & 0.078 \\
ME $^{1}$ milk 305-d milk & & & & \\
production, kg & $13,235 \pm 435$ & $14,995 \pm 463$ & $2,186,253$ & $15,531,421$ & 0.015 \\
Actual corrected 305-d & & & & \\
milk production, kg & $12,508 \pm 372$ & $13,748 \pm 436$ & $1,596,457$ & $6,933,582$ & 0.051 \\
Lactation average SCS & $3.12 \pm 0.3$ & $2.31 \pm 0.3$ & 1.60 & & \\
\hline
\end{tabular}

${ }^{1} \mathrm{ME}=$ Mature equivalent. 
Table 2. Chi-square analysis of SCC $(1000 / \mathrm{mL})$ of cows milked 3 times/d $(3 \times ; \mathrm{n}=17)$ or 6 times/d $(6 \times ; \mathrm{n}=$ 9 ) for the initial $21 \mathrm{~d}$ of lactation. Columns represent the number of cows within each treatment that had SCC $>$ or $<200,000$ cells $/ \mathrm{mL}$ of milk on that test day. Both $\chi^{2}$ and continuity adjusted $\chi^{2}$ significance levels are presented.

\begin{tabular}{|c|c|c|c|c|c|c|}
\hline \multirow[b]{2}{*}{ Test day } & \multicolumn{2}{|c|}{$3 \mathrm{X}$} & \multicolumn{2}{|c|}{$6 \mathrm{X}$} & \multirow[b]{2}{*}{$\chi^{2}$} & \multirow[b]{2}{*}{ Adjusted $\chi^{2}$} \\
\hline & $\begin{array}{l}\text { SCC } \\
<200,000\end{array}$ & $\begin{array}{l}\text { SCC } \\
>200,000\end{array}$ & $\begin{array}{l}\text { SCC } \\
<200,000\end{array}$ & $\begin{array}{l}\text { SCC } \\
>200,000\end{array}$ & & \\
\hline 1 & 11 & 6 & 9 & 0 & 0.013 & 0.043 \\
\hline 2 & 13 & 4 & 9 & 0 & 0.114 & 0.312 \\
\hline 3 & 11 & 6 & 9 & 0 & 0.042 & 0.123 \\
\hline 4 & 13 & 4 & 8 & 1 & 0.444 & 0.809 \\
\hline 5 & 12 & 5 & 8 & 1 & 0.292 & 0.572 \\
\hline 6 & 10 & 7 & 6 & 3 & 0.696 & 1.000 \\
\hline 7 & 13 & 4 & 9 & 0 & 0.114 & 0.312 \\
\hline 8 & 13 & 4 & 9 & 0 & 0.114 & 0.312 \\
\hline 9 & 13 & 4 & 8 & 1 & 0.444 & 0.809 \\
\hline 10 & 13 & 4 & 7 & 2 & 0.940 & 1.000 \\
\hline
\end{tabular}

(Table 1). Similar increases were observed for mature equivalent milk and milk production corrected for components in the $6 \times$ cows relative to those milked $3 \times$ (Table 1). Compared with $3 \times$ cows, $6 \times$ cows had higher summit and peak milk yield and achieved peak at fewer days in milk (Table 1).

Results of the present study are consistent with previous reports that a "window" in early lactation exists when $6 \times$ milking frequency causes milk yield responses that persist for the entire lactation, even after milking frequency is reduced to $3 \times$ (Bar-Peled et al., 1995; Henshaw et al., 2000). In addition, our results extend those studies by indicating that the window is not $42 \mathrm{~d}$, but as little as $21 \mathrm{~d}$, which is in agreement with a report by Hale et al. (2003) that $21 \mathrm{~d}$ of milking at a frequency of 4 times/d was sufficient to produce persistent, positive effects on milk yield for that lactation relative to control cows milked 2 times/d. Further, results of the present study support the concept that as little as a 2$\mathrm{h}$ interval between milkings is sufficient to induce the persistent response. Hale et al. (2003) had previously identified this interval as $3 \mathrm{~h}$ when cows were milked 4 vs. 2 times/d in early lactation.

In addition to the production responses, $6 \times$ cows also had lower SCS relative to $3 \times$ cows. This reduction in SCS was most apparent during the $21 \mathrm{~d}$ when milking frequency was increased, but a tendency $(P=0.138)$ for this decrease in SCS persisted for the entire lactation (Table 1). Examination by Chi-square analysis using a $200,000-c e l l / \mathrm{mL}$ cutoff provided further evidence of improved udder health with more frequent milking (Table 2). Previous reports indicate that milking frequency is inversely related to indices of udder health such as SCS (Kelly et al., 1998; Smith et al., 2002); however, those studies examined SCS while the cows were milked at higher frequency and did not note effects after milking frequency was reduced. Our data support the concept of an inverse relationship between milking frequency and SCS while cows are milked more frequently, but also suggest that there may be a persistent effect of early lactation milking frequency on SCS.

A potential mechanistic explanation for the responses of milk yield and udder health is the impact of milking frequency on prolactin (PRL) release, particularly in early lactation. Prolactin promotes differentiation of mammary epithelial cells, and an increase in the number of fully differentiated mammary cells would be expected to be associated with greater milk yield (Akers et al., 1981; Capuco et al., 2001). Circulating PRL increases in response to milking (Tucker, 1971); thus, cows milked $6 \times$ would have double the number of daily PRL release events that $3 \times$ cows experience. We observed that increased milking frequency from 1 to 21 $\mathrm{d}$ in milk is associated with an increase not only in PRL but in the expression of PRL receptor as well (Dahl et al., 2002), which suggests that cows milked more frequently are more sensitive to PRL and might have greater numbers of mammary cells that differentiate and produce milk during that lactation. Evidence from our laboratory supports the concept that alteration of PRL sensitivity, particularly increases in PRL receptor expression, enhances immune function both in vitro and in vivo (Auchtung et al., 2003a,b). Therefore, shifts in PRL sensitivity may underlie the observed improvements in milk yield and udder health observed when cows are milked at higher frequencies in the initial 21 d of lactation.

\section{REFERENCES}

Akers, R. M., D. E. Bauman, A. V. Capuco, G. T. Goodman, and H. A. Tucker. 1981. Prolactin regulation of milk secretion and biochemical differentiation of mammary epithelial cells in periparturient cows. Endocrinology 109:23-30.

Auchtung, T. L., P. E. Kendall, J. L. Salak-Johnson, T. B. McFadden, and G. E. Dahl. 2003a. Photoperiod and bromocriptine treatment 
effects on expression of prolactin receptor mRNA in bovine liver, mammary gland, and peripheral blood lymphocytes. J. Endocrinol. 179:347-356.

Auchtung, T. L., D. E. Morin, C. Mallard, and G. E. Dahl. 2003b. Photoperiod manipulation during the dry period: Effects on general health and mastitis occurrence. Pages 278-279 in Proc. Natl. Mast. Counc. 42nd Mtg., Fort Worth, TX. National Mastitis Council, Madison, WI.

Bar-Peled, U., E. Maltz, I. Bruckental, Y. Folman, Y. Kali, H. Gacitua, A. R. Lehrer, C. H. Knight, B. Robinzon, H. Voet, and H. Tagari. 1995. Relationship between frequent milking or suckling in early lactation and milk production of high producing dairy cows. J. Dairy Sci. 78:2726-2736.

Capuco, A. V., D. L. Wood, R. Baldwin, K. Mcleod, and M. J. Paape. 2001. Mammary cell number, proliferation, and apoptosis during a bovine lactation: Relation to milk production and effect of bST. J. Dairy Sci. 84:2177-2187.

Dahl, G. E., T. L. Auchtung, J. P. Underwood, and J. K. Drackley. 2002. Frequent milking in early lactation that increases milk yield also increases prolactin receptor mRNA expression. J. Anim. Sci. 80(Suppl. 1):53. (Abstr.)
Hale, S. A., A. V. Capuco, and R. A. Erdman. 2003. Milk yield and mammary growth effects due to increased milking frequency during early lactation. J. Dairy Sci. 86:2061-2070.

Henshaw, A. H., M. Varner, and R. A. Erdman. 2000. The effects of six times a day milking in early lactation on milk yield, milk composition, body condition and reproduction. J. Dairy Sci. 83(Suppl. 1):242. (Abstr.)

Kelly, A. L., S. Reid, P. Joyce, W. J. Meaney, and J. Foley. 1998. Effect of decreased milking frequency of cows in late lactation on milk somatic cell count, polymorphonuclear leucocyte numbers, composition and proteolytic activity. J. Dairy Res. 65:365-373.

Smith, J. W., L. O. Ely, W. M. Graves, and W. D. Gilson. 2002. Effect of milking frequency on DHI performance measures. J. Dairy Sci. 85:3526-3533.

Stelwagen, K. 2001. Effect of milking frequency on mammary function and shape of the lactation curve. J. Dairy Sci. 84(E. Suppl.):E204-E211.

Tucker, H. A. 1971. Hormonal response to milking. J. Anim. Sci. 32(Suppl 1):137-144.

Young, C. W., W. J. Tyler, A. E. Freeman, H. H. Voelker, L. D. McGilliard, and T. M. Ludwick. 1969. Inbreeding investigations with dairy cattle in the north central United States. Tech. Bull. 266, North Central Reg. Res. Publ. 191. Agricultural Experiment Station, University of Minnesota, St. Paul, MN. 